\title{
Rhizosphere microbiome: revisiting the synergy of plant-microbe interactions
}

\author{
Saritha Mohanram ${ }^{1}$ - Praveen Kumar ${ }^{1}$ \\ Received: 26 September 2018 / Accepted: 5 February 2019 / Published online: 23 February 2019 \\ (C) Università degli studi di Milano 2019
}

\begin{abstract}
Sustainable enhancement in food production from less available arable land must encompass a balanced use of inorganic, organic, and biofertilizer sources of plant nutrients to augment and maintain soil fertility and productivity. The varied responses of microbial inoculants across fields and crops, however, have formed a major bottleneck that hinders its widespread adoption. This necessitates an intricate analysis of the inter-relationships between soil microbial communities and their impact on host plant productivity. The concept of "biased rhizosphere," which evolved from the interactions among different components of the rhizosphere including plant roots and soil microflora, strives to garner a better understanding of the complex rhizospheric intercommunications. Moreover, knowledge on rhizosphere microbiome is essential for developing strategies for shaping the rhizosphere to benefit the plants. With the advent of molecular and "omics" tools, a better understanding of the plant-microbe association could be acquired which could play a crucial role in drafting the future "biofertilizers." The present review, therefore aims to (a) to introduce the concepts of rhizosphere hotspots and microbiomes and (b) to detail out the methodologies for creating biased rhizospheres for plant-mediated selection of beneficial microorganisms and their roles in improving plant performance.
\end{abstract}

Keywords Biased rhizosphere $\cdot$ Microbial inoculants $\cdot$ Microbiome $\cdot$ Rhizosphere engineering $\cdot$ Root border cells

\section{Introduction}

Biofertilizers are preparations containing specialized living organisms that can fix, mobilize, solubilize, or decompose nutrient sources which, when applied through seed or soil, enhance nutrient uptake by plants. Biofertilizer research started with "Nitragin," the first commercially produced and patented culture of Rhizobium, by Nobbe and Hiltner in 1895 (Nobbe and Hiltner 1896). The introduction of yellow seeded soybean in India in the 1960s led to a spurt in demand for soybean inoculants in the region. This intensified research in development of microbial formulations for pulses, groundnut, and even forage legumes. The discovery of Azotobacter, Azospirillum, blue-green algae and a host of other beneficial microorganisms soon followed. Interestingly, "biofertilizer" is a misnomer and the term "microbial inoculants" better suit

Saritha Mohanram

sarithamohanram@gmail.com

1 Division of Integrated Farming System, ICAR-Central Arid Zone Research Institute, Jodhpur, Rajasthan 342003, India these plant growth-promoting organisms, which are capable of exerting beneficial effects on plants. Generally, 60-90\% of the total applied fertilizer is lost and in this regard, microbial inoculants have prominence in sustainable integrated nutrient management systems (Bhardwaj et al. 2014). Moreover, the utility of poor-quality native nutrients in soil necessitates microbial interventions. For example, approximately $90 \%$ of total soil $\mathrm{K}$ is found in crystalline, insoluble mineral forms like feldspars and mica, which plants cannot utilize (Meena et al. 2014). To make them available for plant nutrition, microorganisms which can solubilize and release $\mathrm{K}$ should be deployed.

While positive responses have been recorded in a range of field trials, the beneficial effects from the application of microbial inoculants are found to differ greatly under different agro-environmental conditions and this has resulted in inconsistency in responses across crops and regions (Table 1). There are also reports on the efficacy of microbial inoculants on particular varieties of crops, but not others. For example, the Rhizobium strain $\mathrm{G}_{2}$, which increased the yield of four chickpea varieties - $\mathrm{T}_{3}$, Gwalior 2 , G-130, and Pusa-53 - was ineffective on the varieties R.S.II and N-59 (Sundara Rao 1974). This suggests the host plant-specificity and strain-specificity 
Table 1 Varied responses of crops to microbial inoculation

\begin{tabular}{|c|c|c|c|}
\hline Microbial inoculant & Crop & Remarks & Reference \\
\hline Bacillus megaterium & $\begin{array}{l}\text { Vegetable crops, grains, } \\
\text { and potatoes }\end{array}$ & Yield increases of $0 \%-70 \%$ & Smith et al. (1961) \\
\hline Rhizobium & Chickpea & Yield ranging from 30 to $610 \mathrm{~kg} / \mathrm{ha}$ & Subba Rao (1976) \\
\hline Arbuscular mycorrhizal fungi & Various crops & $\begin{array}{l}\text { Negative interactions to } 14 \text {-fold yield } \\
\text { increase }\end{array}$ & $\begin{array}{l}\text { Black and Tinker (1979), McGonigle (1988), } \\
\text { Owusu-Bennoah and Mosse (1979) }\end{array}$ \\
\hline Associative nitrogen-fixing bacteria & Rice & Yield increases of $10 \%-30 \%$ & Chongbiao (1990) \\
\hline Azotobacter & Wheat & Yield ranging from 34 to $247 \mathrm{~kg} / \mathrm{ha}$ & Hegde and Dwivedi (1994) \\
\hline $\begin{array}{l}\text { Azospirillum brasilense and } \\
\text { Bacillus circulans }\end{array}$ & Flax and cereals & Yield increases of $8 \%-30 \%$ & Mikhailouskaya and Bogdevitch (2009) \\
\hline Azospirillum & Wheat & $12.9 \%-22.5 \%$ increase in dry weight & Veresoglou and Menexes (2010) \\
\hline $\begin{array}{l}\text { Pseudomonas, Azospirillum, } \\
\text { Azotobacter, Bacillus }\end{array}$ & $\begin{array}{l}\text { Maize, wheat, sunflower, } \\
\text { lettuce }\end{array}$ & Yield increases of $19 \%-40 \%$ & Rubin et al. (2017) \\
\hline
\end{tabular}

associated with microbial inoculants. Several physical, chemical, and biological factors affect the survival and functioning of microorganisms in the soil. Soil water deficit and high temperature are the major abiotic factors that affect their performance in dryland agriculture. Inadequacy of soil organic matter further aggravates the problem as the non-symbiotic microorganisms depend on organic matter for energy and growth. Microbial inoculation in soil also influences the activity of indigenous microflora, ultimately having a bearing on their own survival (Ramos et al. 2003). This is because the introduced microorganism must adhere to the plant roots, compete for space and nutrients released through root exudation, and must be able to occupy the new niche in sufficient numbers so as to exert its effect on the host plant (Barriuso et al. 2008b). Often, the native inhabitants of soil, which are better adapted to the environmental conditions, outcompete the inoculated population. Development of an effective microbial inoculant thus requires the presence of multiple fitness traits that can facilitate its colonization and survival under harsh environmental conditions (Rana et al. 2011). To facilitate this, bioprospecting for more tolerant strains and novel methodologies for understanding the plant-microbe interactions are necessitated.

\section{The rhizospheric hotspot of plant microbiome}

In spite of the vast microbial diversity in soil, microorganisms are congregated in small pockets which constitute only $1 \%$ of the total soil volume (Young et al. 2008). These microhabitats wherein microorganisms are aggregated to form colonies or biofilms are characterized by faster rates of different biogeochemical processes than bulk soil (Kuzyakov 2009). Kuzyakov and Blagodatskaya (2015) defined these soil volumes as "microbial hotspots" and identified four such hotspots in soil. These include (a) rhizosphere, the region of soil surrounding living roots which is under the influence of plant root exudates; (b) detritusphere, the soil region associated with decomposition of plant litter and turnover of soil organic matter; (c) biopores, formed by deep growing roots and burrowing fauna; and (d) the soil aggregate surfaces (Kautz 2015; Kramer et al. 2016; Kuzyakov and Blagodatskaya 2015). These regions provide inputs of labile and recalcitrant organics for bioprocesses and are also relevant with respect to the factors like soil moisture, oxygen availability, and nitrogen nutrition, which limit microbial activity (Kuzyakov and Blagodatskaya 2015).

The localized availability of labile carbon and other readily utilizable nutrients leads to a concentration of events like respiration, gas exchange, nutrient and moisture utilization, and other bioprocesses in the rhizosphere (Richter et al. 2011). The major phenomenon underlying the establishment of such distinct rhizosphere characteristic is rhizodeposition, wherein plant roots secrete a wide range of low- and high-molecular weight compounds including sugars, organic acids, amino acids, polysaccharides, vitamins, and other secondary metabolites into the surrounding soil (Badri and Vivanco 2009). These rhizodeposits account for $\sim 11 \%$ of net photosynthetically fixed carbon and 10-16\% of total plant nitrogen (Jones et al. 2009). These exudates play an important role in shaping the rhizosphere by altering soil chemistry in the immediate vicinity of plant roots and by serving as substrates for the growth of selected soil microorganisms (Yang and Crowley 2000). Components of plant root exudates get varied, both qualitatively and quantitatively, depending on the nutritional status of the plant, growth stage, and even in time and space relative to the position of the root (Hartmann et al. 2009; Malusà et al. 2016). This creates a strong selective pressure in the rhizosphere leading to a plant-driven selection of specific rhizosphere microbial communities. Interestingly, only $2-5 \%$ of the rhizosphere microorganisms promote plant growth (Antoun and Kloepper 2001) and plants naturally select for these 
beneficial microorganisms which help in their growth and survival, especially under constrained conditions (Lareen et al. 2016). The rhizosphere microorganisms may also enter the roots and migrate to the plant's aerial surfaces (phyllosphere) (Thapa and Prasanna 2018) and internal tissues (endosphere). Hence, plants are often associated with communities of microorganisms, living on or within them, exhibiting mutually beneficial symbioses. This entire genome of microbial community, referred to as the microbiome, plays vital roles in host's nutrient uptake, metabolic capabilities and tolerance to biotic and abiotic stresses (Bulgarelli et al. 2013; Sessitsch and Mitter 2015). Therefore, defining a host plant's core distinct microbiome that supports its growth is the preliminary step in improving the plant's characteristic traits.

\section{Significance of plant microbiome on crop growth}

In an ecological perspective, plants are more than individual entities as they co-habit with the plant microbiota that impact plant growth and productivity. The microbial diversity of soil and rhizosphere microbiomes is highly underestimated as only $5 \%$ of microorganisms have been cultured by current methodologies (Mendes et al. 2013). The plant-associated microbiomes consist of beneficial organisms like nitrogenfixing bacteria, mycorrhizal fungi, other plant growthpromoting rhizobacteria (PGPR), and biocontrol agents, as well as organisms that are deleterious to plant growth like pathogenic microorganisms. Next-generation sequencing technologies based on 16S rRNA gene have illustrated the vast diversity of microorganisms, particularly bacteria, present in the core microbiome of plants (Table 2). Hawkes et al. (2007) conducted a meta-analysis of clone libraries obtained from the rhizosphere of 14 different plant species and found that the plants were associated with more than 1200 bacterial taxa and the phylum Proteobacteria was the most dominant. These assemblages of plants and microorganisms deal with perturbations in the surroundings by detecting and responding to environmental stimuli, resulting in specific adjustments in their growth and development. As opined by Gopal and Gupta (2016), the overall fitness of the plant depends greatly on the ecological services of plant-associated microorganisms that include biofertilization, protection from diseases and tolerance to abiotic stresses.

\section{Role of plant microbiome in nutrient acquisition}

Research on plant microbiome actually started with the earliest observations of legume-Rhizobium and mycorrhizal symbiotic relationships. Rhizobia fix atmospheric nitrogen in a form that is utilized by legumes and in turn depend on host for photosynthates and for some of the genes involved in nitrogen fixation (Hunter 2016). Mycorrhizal fungi enhance the nutrient absorptive capacity of roots by increasing the effective surface area and the release of hydrolytic enzymes. Besides nutrient translocation, mycorrhizae also improve soil structure by creating stable soil aggregates (Rillig 2004). The similarity in signaling crosstalk and the similar cellular responses of the rhizobial and mycorrhizal symbionts led to the establishment that the rhizobium-legume symbiosis recruited mechanisms established to support the more ancient endosymbiotic relationship with arbuscular mycorrhizal fungi (Rogers and Oldroyd 2014; Streng et al. 2011). However, understanding the fundamental differences between the two responses is crucial in realizing the age-old dream of developing in planta systems to transform cereals into autonomous Nfixing plants, by engineering into them the legume symbiosis pathway (Geurts et al. 2012).

Several other nitrogen-fixing endophytic and free-living rhizobacteria of the genera Bradyrhizobium, Azotobacter, Pseudomonas, Azospirillum, Bacillus, Burkholderia, and Achromobacter have been found to have positive impacts on crops by enhancing both above and belowground biomass (Guimarães et al. 2012; Gyaneshwar et al. 2011; Igiehon and Babalola 2018). Several phosphate-solubilizing bacteria (Pseudomonas, Bacillus, Alcaligenes, Aerobactor) and fungi (Aspergillus, Penicillium, Fusarium, Chaetomium, Cephalosporium) are also important members of the plant microbiome (Chen et al. 2006; Sharma et al. 2013; Uribe et al. 2010). They increase the solubility of inorganic phosphorus $(\mathrm{P})$ by releasing protons, $\mathrm{OH}^{-}$, or $\mathrm{CO}_{2}$, and organic acid anions such as citrate, malate, and oxalate and can also mineralize organic $\mathrm{P}$ by release of various phosphatase enzymes (Marschner et al. 2010). Rhizosphere microorganisms also facilitate the uptake of trace elements such as iron (Fe) and zinc $(\mathrm{Zn})$. Microorganisms release organic acid anions or siderophores that chelate ferric ion $\left(\mathrm{Fe}^{3+}\right)$ and transfer it to the cell surface where it gets reduced to the soluble ferrous ion $\left(\mathrm{Fe}^{2+}\right)$ (Mendes et al. 2013). These siderophores include enterobactin, pyoverdine, and ferrioxamines produced by bacteria and ferrichromes produced by fungi (Marschner et al. 2010). Fluorescent pseudomonads have been found to promote iron nutrition via siderophores for Graminaceous as well as dicotyledonous plant species (Shirley et al. 2011). Rhizosphere microorganisms (Curtobacterium, Plantibacter, Pseudomonas, Stenotrophomonas, Streptomyces) are also known to mobilize zinc ( $\mathrm{Zn}$ ) by acidification of medium via gluconic acid production (Costerousse et al. 2018; Whiting et al. 2001).

The rhizosphere microbiome also plays an important part in organic matter decomposition which enhances soil fertility and ultimately improves plant productivity. Lignocellulolytic fungi like Trichoderma harzianum, Pleurotus ostreatus, Polyporus ostriformis, and Phanerochaete chrysosporium 
Table 2 Vast diversity of microorganisms identified in the rhizosphere microbiome of plants

\begin{tabular}{|c|c|c|}
\hline Host plant & Dominant members of the rhizosphere microbiome & Reference \\
\hline Oak & $\begin{array}{l}\text { (Characterized by } 16 \mathrm{~S} \text { rRNA gene sequencing) identified } \\
5619 \text { bacterial OTUs (operational taxonomic unit) with } \\
38 \% \text { Proteobacteria, } 24 \% \text { Acidobacteria, } 11 \% \\
\text { Actinobacteria, and } 20 \% \text { unclassified bacteria }\end{array}$ & Uroz et al. (2010) \\
\hline \multirow[t]{2}{*}{ Sugarbeet } & (Characterized by $16 \mathrm{~S}$ rRNA gene microarray) & Mendes et al. (2011) \\
\hline & $\begin{array}{l}\text { Detected } 33,346 \text { bacterial and archaeal OTUs, of which } 39 \% \\
\text { were Proteobacteria (Gamma- and Betaproteobacteria), } \\
20 \% \text { were Firmicutes, } 9 \% \text { were Actinobacteria }\end{array}$ & \\
\hline \multirow[t]{2}{*}{ Rice } & (Characterized by 16S rRNA gene sequencing) & Edwards et al. (2015) \\
\hline & $\begin{array}{l}\text { Bacteroidetes, Firmicutes, Chloroflexi, and } \\
\text { Betaproteobacteria (Rhodocyclaceae, } \\
\text { Comamonadaceae), Alphaproteobacteria, } \\
\text { Deltaproteobacteria }\end{array}$ & \\
\hline \multirow[t]{2}{*}{ Sugarcane } & (Characterized by $16 \mathrm{~S}$ rRNA gene sequencing) & Yeoh et al. (2016) \\
\hline & $\begin{array}{l}\text { Betaproteobacteria (Undibacterium, Burkholderia), } \\
\text { Alphaproteobacteria (Bradyrhizobium, Rhizobium), } \\
\text { Bacteroidetes (Niastella, Chitinophaga), } \\
\text { Gammaproteobacteria (Dyella, Frateuria), Actinobacteria } \\
\text { (Streptomyces, Cryocola), Chloroflexi and Firmicutes } \\
\text { (Bacillus) }\end{array}$ & \\
\hline \multirow[t]{2}{*}{ Sugarcane } & $\begin{array}{l}\text { (Characterized by sequencing of 16S and ITS ribosomal } \\
\text { RNA genes) }\end{array}$ & de Souza et al. (2016) \\
\hline & $\begin{array}{l}\text { Identified 23,811 bacterial OTUs and 11,727 fungal OTUs. } \\
\text { Major families were Chitinophagaceae, } \\
\text { Rhodospirillaceae, Hyphomicrobiaceae, } \\
\text { Burkholderiaceae, Rhizobiaceae, Sphingobacteriaceae, } \\
\text { Sphingomonadaceae, Sistotremataceae, Meruliaceae, } \\
\text { Ceratocystidaceae, Chaetosphaeriaceae, Glomeraceae }\end{array}$ & \\
\hline \multirow[t]{2}{*}{ Oilseed rape } & $\begin{array}{l}\text { (Characterized by RNA stable isotope probing and } \\
\text { high-throughput sequencing) }\end{array}$ & Gkarmiri et al. (2017) \\
\hline & $\begin{array}{l}\text { Verrucomicrobia, Proteobacteria, Planctomycetes, } \\
\text { Acidobacteria, Gemmatimonadetes, Actinobacteria, } \\
\text { Flavobacterium, Rhodoplanes, Sphingomonas, } \\
\text { Streptomyces, Chloroflexi, Rhizobium }\end{array}$ & \\
\hline \multirow[t]{2}{*}{ Arabidopsis thaliana } & (Characterized by sequencing of the ITS2 region) & Urbina et al. (2018) \\
\hline & $\begin{array}{l}\text { Ascomycetes (542 OTUs) and Basidiomycetes (145 OTUs) } \\
\text { were the abundant phyla, and Archaeorhizomycetes, } \\
\text { Leotiomycetes, Dothideomycetes, Eurotiomycetes and } \\
\text { Sordariomycetes were the abundant classes }\end{array}$ & \\
\hline \multirow[t]{2}{*}{ Canola } & $\begin{array}{l}\text { (Characterized by sequencing of } 16 \mathrm{~S} \text { and ITS ribosomal } \\
\text { RNA genes) }\end{array}$ & Lay et al. (2018) \\
\hline & $\begin{array}{l}\text { Identified } 6376 \text { bacterial OTUs, } 679 \text { fungal OTUs and } 49 \\
\text { archaeal OTUs, including Amycolatopsis sp., Serratia } \\
\text { proteamaculans, Pedobacter sp., Arthrobacter sp., } \\
\text { Stenotrophomonas sp., Fusarium merismoides, Fusicolla sp. }\end{array}$ & \\
\hline \multirow[t]{2}{*}{ Blueberry } & $\begin{array}{l}\text { (Characterized by } 16 \mathrm{~S} \text { rRNA and 18S rRNA gene } \\
\text { sequencing) }\end{array}$ & Yurgel et al. (2018) \\
\hline & $\begin{array}{l}\text { Abundant bacterial classes were Proteobacteria } \\
\text { (Alphaproteobacteria and Gammaproteobacteria), } \\
\text { Acidobacteria, Actinobacteria, Bacteroidetes, } \\
\text { Saprospirae, Chloroflexi, Ktedonobacteria, and } \\
\text { Verrucomicrobia Spartobacteria. Fungal taxa identified } \\
\text { were Ascomycota, Basidiomycota, Mucoromycota, } \\
\text { Glomeromycota, and Chytridiomycota }\end{array}$ & \\
\hline
\end{tabular}

and bacteria like Pseudomonas sp., Cellulomonas sp., Cytophaga sp., Sporocytophaga sp., Chryseobacterium gleum, and Streptomyces sp. are known to degrade plant biomass, thereby releasing nutrients not only for their own nutrition, but also for plant nutrition (Ahmed et al. 2018; Mendes et al. 2013; Singh and Nain 2014; Woo et al. 2014). The plant microbiome, therefore, facilitates the growth of plants even in nutrient-poor soils. 


\section{Role of plant microbiome in protection from pathogens and host immunity}

The rhizosphere antagonistic microorganisms ward off pathogens by producing antibiotics or hydrolytic enzymes and also by competing for nutrients and space (Caravaca et al. 2015; Raaijmakers and Mazzola 2012). Antimicrobial metabolites produced by microorganisms include ammonia, butyrolactones, oligomycin A, phenazine-1-carboxylic acid (PCA), pyoluterin, pyrrolnitrin, and other moieties (Wackett 2013; Whipps 2001). Pseudomonas fluorescens suppresses soilborne pathogens like Meloidogyne incognita and Fusarium oxysporum by production of the antibiotic 2,4diacetylphloroglucinol (DAPG) (Meyer et al. 2016). Bacteria are also known to parasitize and degrade spores of fungal plant pathogens through the production of extracellular cell walldegrading enzymes such as chitinase and $\beta-1,3$ glucanase (Whipps 2001). Most microbial biocontrol strains produce more than one antibiotic compound with varying degrees of antimicrobial activity. Agrobacterium radiobacter produces agrocin 84 , which is antibiotic to closely related strains, and polyketide antibiotics which are broad-spectrum in nature (Raaijmakers et al. 2010). Bacterial iron chelators also effectively play a role in the biocontrol of pathogens by sequestering the available iron and making it unavailable to pathogenic microorganisms, thereby restricting their growth. Siderophores produced by Bacillus subtilis significantly managed the Fusarium wilt of pepper caused by Fusarium oxysporum (Yu et al. 2011). Siderophores produced by Aspergillus niger, Penicillium citrinum, and Trichoderma harzianum were found to be effective biocontrol agents and enhanced the growth of chickpeas (Cicer arietinum) (Yadav et al. 2011).

Rhizobacteria, particularly Pseudomonas and Bacillus, could also act as elicitors for inducing systemic resistance against pathogens in some plants. The siderophores produced by Pseudomonas aeruginosa, pyoverdine, pyochelin, and its precursor salicylic acid (SA), can induce resistance to diseases caused by Botrytis cinerea on bean and tomato, Colletotrichum lindemuthianum on bean, and tobacco mosaic virus on tobacco (Bigirimana and Höfte 2002; Höfte and Bakker 2007). Similarly, the catechol-type siderophore produced by Serratia marcescens 90-166 induces resistance to fungal, viral, and bacterial pathogens such as Colletotrichum orbiculare, Fusarium oxysporum, cucumber mosaic virus, Pseudomonas syringae, and Erwinia tracheiphila in cucumber (Press et al. 2001). The rhizobacterial association trigger either the salicylic acid dependent signal transduction pathway or the jasmonic acid and ethylene signaling pathway for protection against pathogens (Ton et al. 2002). Plants with such induced resistance show strengthening of epidermal and cortical cell walls by deposition of callose, lignin, and phenolics, increased levels of enzymes such as chitinase, peroxidase, polyphenol oxidase, and phenylalanine ammonia lyase, enhanced phytoalexin production, and enhanced expression of stress-related genes (Heil and Bostock 2002; Whipps 2001; Yi et al. 2013). Therefore, multiple microbial interactions in the rhizosphere provide enhanced biocontrol against pathogens, besides modulating the plant immune system.

\section{Role of plant microbiome in tolerance to abiotic stresses}

Rhizosphere microorganisms, with their intrinsic metabolic and genetic capabilities, contribute to alleviate abiotic stresses in plants (Gopalakrishnan et al. 2015). Several microflora of the genera Pseudomonas, Bacillus, Achromobacter, Burkholderia, Enterobacter, Azotobacter, Methylobacterium, and Trichoderma have been widely studied in plant growth promotion by mitigation of multiple kinds of abiotic stresses (Atieno et al. 2012; Meena et al. 2017; Sorty et al. 2016). Wheat inoculated with Burkholderia phytofirmans PsJN reported an increased photosynthesis, high chlorophyll content, and grain yield than the control under water deficit in field conditions (Naveed et al. 2014). Treatment of Indian mustard (Brassica juncea) with the fungus, Trichoderma harzianum, improved the uptake of essential nutrients and enhanced accumulation of antioxidants and osmolytes and decreased $\mathrm{Na}^{+}$ uptake under saline conditions (Ahmad et al. 2015). Better root colonizing capability of Pseudomonas sp. along with its ability to produce exopolysaccharides led to enhanced tolerance towards salinity (Sen and Chandrasekhar 2014). Volatile organic carbons emitted from Bacillus subtilis GB03 were found to downregulate the $H K T 1$ (high-affinity $\mathrm{K}^{+}$transporter 1) expression in roots of Arabidopsis and upregulate it in shoots, resulting in lower $\mathrm{Na}^{+}$accumulation throughout the plant thereby inducing tolerance to salt stress (Zhang et al. 2008). Srivastava et al. (2008) isolated a thermotolerant Pseudomonas putida strain NBR10987 from droughtstressed rhizosphere of chickpea and the strain was able to combat stress by producing exopolysaccharides with unique water holding characteristics. Rhizosphere microorganisms also increase tolerance to low nonfreezing temperatures resulting in higher and faster accumulation of stress-related proteins and metabolites (Theocharis et al. 2012). Novel stress tolerant bacteria such as Brachybacterium saurashtrense, Zhihengliuella sp., and Brevibacterium casei have also been reported from plant rhizospheres (Jha et al. 2012). Moreover, the bacteria such as Pseudomonas, Microbacterium, Verrucomicrobia, and Actinobacteria and fungi such as Lewia sp. and mycorrhizal fungi are potential candidates for rhizoremediation as they alter the mobility and bioavailability of metals, thereby increasing their uptake by plants (Cruz-Hernández et al. 2012; Kawasaki et al. 2012; Yang et al. 2016). 


\section{Role of plant microbiome in phytohormone production}

Plant growth-promoting rhizobacteria and fungi are known to improve plant growth by the production of phytohormones. These plant hormones are mostly synthesized as secondary metabolites as they are not essential for the growth and reproduction of microorganisms (Shi et al. 2017). Gibberellins were firstly discovered when it was noticed that a chemical synthesized in Gibberella fujikuroi can contribute to the disease of rice plants (Kurosawa 2003). Gibberellins can stimulate plant growth and regulate various developmental processes like seed germination, stem elongation, sex expression, and fruit formation (Bömke and Tudzynski 2009). Production of gibberellin-like substances have been reported in numerous bacterial genera including Azospirillum sp., Rhizobium sp., Acetobacter diazotrophicus, Herbaspirillum seropedicae, Bacillus sp., and Fusarium moniliforme (Bottini et al. 2004; Meleigy and Khalaf 2009). Auxin and cytokinin production are thought to be involved in root growth stimulation by beneficial bacteria and in associative symbiosis. Auxin biosynthesis by Pseudomonas, Agrobacterium, Rhizobium, Bradyrhizobium, Azospirillum, Botrytis, Aspergillus, and Rhizopus are well studied (Costacurta and Vanderleyden 1995; Hui et al. 2007). Apart from synthesis, plantassociated microorganisms also alter the hormonal signaling in plants, in response to environmental stimuli. As stated in a previous section, the systemic resistance response induced in plants by beneficial rhizobacteria is in many cases regulated by the phytohormones jasmonic acid and ethylene (Zamioudis and Pieterse 2012). Therefore, microorganism-mediated phytohormone production is a potent mechanism to alter plant physiology, leading to diverse outcomes from pathogenesis to promotion of plant growth (Spaepen 2014).

\section{Role of microbiome in impairing plant health and productivity}

Besides plant growth-promoting microorganisms, the root microbiome also consists of rhizosphere microorganisms which are detrimental to plants, competing for nutrients and space. Plant pathogenic fungi, bacteria, and nematodes cause various plant diseases resulting in substantial economic damage to crops. Agrobacterium tumefaciens, Ralstonia solanacearum, Dickeya sp., Pectobacterium carotovorum, Pythium sp., Phytopthora sp., Fusarium oxysporum, Rhizoctonia sp., Gaeumannomyces graminis, Colletotrichum sp., and Magnaporthe oryzae are a few of the major plant pathogenic microorganisms prevalent in soils (Dean et al. 2012; Doehlemann et al. 2017; Mansfield et al. 2012). The phenolic compounds present in plant root exudates, in low concentrations, facilitate conidial germination, while in higher concentrations; inhibit mycelia growth (Mendes et al. 2013).
Bacteria and fungi are two major groups of the plant microbiome, and their interactions via antibiosis, modulation of the physiochemical environment, cooperative metabolism, protein secretion, or even gene transfer can lead to either antagonism or cooperation (Chen et al. 2018; Frey-Klett et al. 2007). This implies that an alteration of the rhizosphere characteristics can influence plant growth and in this context, shaping the rhizosphere microbiome provides a sound alternative for the conventional microbial inoculation.

\section{Engineering a biased rhizosphere to promote plant-microbe interactions}

Taking into account the role of plant root exudates in attracting rhizosphere microorganisms, altering the root exudate composition, both qualitatively and quantitatively, is a major approach to reshape the rhizosphere microbiome. The creation of a "biased rhizosphere" is a novel procedure which involves the expression of specific genes in transgenic plants that would enable roots to produce the specific nutritional compound, which can be used or recognized by specific beneficial microorganisms (Reddy et al. 2002; Savka et al. 2013). The goal of rhizosphere engineering is to direct the plant-microbe interaction towards enhanced beneficial outcomes including nutrient cycling, mineralization and organic matter decomposition, tolerance to drought, salinity and other abiotic stresses, and resistance to diseases (Marasco et al. 2012; Quiza et al. 2015). The methods of application of microbial inoculants in soil, employment of tillage, plant breeding approaches, and the use of fungicides and antibiotics for plant protection are, to a certain extent, conventional rhizosphere modification strategies. The application of plant growth-promoting rhizobacteria (PGPR), nitrogen fixers, phosphate solubilizers, and arbuscular mycorrhizal fungi (AMF) improve plant performance by enhancing nutrient availability, phytohormone production, and pathogen control. But, maintenance of high population densities of these microorganisms after inoculation is a major constraint owing to their decline over time and distance from the inoculum source (O'Callaghan et al. 2001; Quiza et al. 2015). Similarly, tillage, plant protection measures, and cultivar selection may induce soil vulnerability, even though they may influence microbial populations by inhibiting or enhancing the growth of soil microorganisms (Bakker et al. 2012; Brussaard et al. 2007). Consequently, the avenue of rhizosphere microbiome engineering has emerged which aims to alter the rhizosphere to express a bias towards beneficial microorganisms enabling plants to evolve into better hosts. It harnesses the variations in plant root exudation patterns in order to enhance the favorable rhizosphere microbiome (Philippot et al. 2013; Quiza et al. 2015). Genetic alteration of root exudation patterns could influence microbial communities by enhancing or inhibiting the growth of 
selected microorganisms. The important strategies for rhizosphere modification being researched widely include the manipulation of root border cells, engineering of inhibitors and enhancers, and induction of microbial gene expression in host plant cells.

\section{Tailoring root border cells for creation of biased rhizoshere}

In the process of exudation, roots are found to release a group of metabolically active cells known as border cells into the surrounding soil (O'Connell et al. 1996). These are actually the sloughed-off root cap cells, which are attached to the root surface by a water-soluble polysaccharide matrix (Hawes et al. 2000). In the presence of water, the middle lamellae of these cells become solubilized by the action of pectinolytic enzymes in the cell wall and get dispersed from root tips (Wen et al. 1999). These border cells serve in mucilage secretion, sensing of gravity, and other environmental signals, synthesis, and export of extracellular chemicals, enzymes, antibiotics, and sugars, which can rapidly attract and stimulate growth in some microorganisms or repel and inhibit the growth of others, thereby mediating rhizosphere processes (Hawes et al. 1998, 2000; Jian-Wei et al. 2002). More importantly, border cells remain viable even after their detachment from the root cap and are characterized by distinct mRNA and protein profiles with respect to that of the root cap cells (Brigham et al. 1995; Zhu et al. 2004). The ability of border cells to engineer the chemical and physical properties of the external environment has been demonstrated by their ability to attract fungal spores, to repel pathogenic bacteria, to synthesize defensive structures against pathogen invasion, and to influence gene expression in symbiotic bacteria (Gunawardena and Hawes 2002; Hawes et al. 2000; Somasundaram et al. 2008). These cells, therefore, are attractive targets to be engineered for developing a biased rhizosphere to facilitate association with beneficial microorganisms.

Chemotactic attraction facilitating the association of plant roots and border cells with soil microflora has been reported. Hawes et al. (2000) studied the interaction of root knot nematode with root border cells of pea and found that the nematodes get attracted and immobilized by the border cells. Experiments also revealed that border cells synthesize and export into the surrounding mucilage, histone-linked extracellular DNA (exDNA), which attracts, traps, and immobilizes pathogens in a host-microbe-specific manner (Hawes et al. 2012). Recently, molecular techniques are being used to identify and manipulate the expression of plant genes that control the production and specialized properties of border cells in transgenic plants. Lilley et al. (2011) reported the targeting of inhibitory peptides specifically to root border cells of potato using a root-cap-specific MDK4-20 promoter of Arabidopsis thaliana. The AtMDK4-20 promoter was found to remain active for a long time in the detached border cells and the transgenic potato plants expressed $94.9 \%$ resistance to the potato cyst nematode Globodera pallid (Lilley et al. 2011). Similarly, the expression of Cry proteins in roots and border cells of transgenic cotton, which are involved in controlling lepidopteran pests, was investigated by Knox et al. (2007). ELISA was used to quantify the in vitro expression of Cry1 Ac and Cry2Ab proteins in root border cells of transgenic cultivars of cotton and it was found to be constitutive and at detectable levels (Knox et al. 2007).

Root border cells are also found to impart resistance to aluminum (Al) toxicity (Yu et al. 2009). The responses of root apices of pea (Pisum sativum) to Al exposure in mist culture revealed that border cells enhanced the $\mathrm{Al}$ resistance of root apices by immobilizing $\mathrm{Al}$ in their cell-wall pectin (Yu et al. 2009). Inhibition of root elongation, induction of callose synthesis, and accumulation of $\mathrm{Al}$ were more pronounced in root apices stripped from border cells. Such border cell trapping has also been found to be associated with cadmium, arsenic, copper, lead, mercury, and nickel (Hawes et al. 2016; Huang et al. 2009; Kopittke et al. 2011; Zelko and Lux 2003). Root border cells are also reported to actively take up glucose, and also release it, thereby playing a significant role in the net glucose exchange in rhizosphere (Stubbs et al. 2004). These aspects could be effectively utilized to drive the rhizospheric characteristics towards better plant-microbe associations and plant growth. The ability of root border cells to produce mucilage can be employed for better penetration of root tips through hard soils and mineral surfaces for better uptake of water and nutrients. The negatively charged groups on side chains of mucilagenous polysaccharides of root border cells can also facilitate attraction of cations like $\mathrm{Ca}^{2+}$, providing exchange sites from which roots might absorb nutrients (Brundrett et al. 2016). In this way, the thousands of border cells released by plant roots can be tailored to engineer the rhizosphere to suit plant health and nutrition.

\section{Engineering inhibitors and enhancers in plants to induce rhizosphere bias}

Plants can be genetically modified to alter soil organic anion efflux and transportation from roots by engineering plants with a greater capacity to synthesize organic anions and to transport them out of the cell (Quiza et al. 2015). Plants engineered with higher ability to excrete citrate from the roots grew better on P-limited soil than the wild type, indicating their ability to grow in acid soils (Koyama et al. 1999). Root-secreted organic acids, such as malate and citrate, optimize the carbon economy of soil microorganisms as they are easily consumed by the microflora (Wu et al. 2018). Also, the organic acid-chemotaxis regulates the recruitment of beneficial rhizobacteria to the root surface (Rudrappa et al. 2008). In tobacco and alfalfa plants genetically engineered to 
overproduce citric or malic acid, an increased colonization by mycorrhizal fungi and rhizobacteria has been reported (López-Bucio et al. 2000; Tesfaye et al. 2003). In other studies, rhizosphere $\mathrm{pH}$ has been altered by over-expressing the genes controlling proton efflux from plant cells (Ryan et al. 2009). Tobacco plants transformed with a modified plasma membrane proton pump ATPase $\left(\mathrm{H}^{+}\right.$-ATPase) exhibited increased $\mathrm{H}^{+}$-efflux from roots and a more acidic rhizosphere (Gévaudant et al. 2007). The edaphic variables, especially $\mathrm{pH}$, shape the structure and function of microbial communities in the rhizosphere (Fierer and Jackson 2006). However, Yuan et al. (2008), by transcriptome profiling and functional analysis, have revealed that an acidic soil $\mathrm{pH}$ induces the virulence of Agrobacterium tumefaciens. Plants may also be engineered to promote the growth of desired microorganisms by releasing nutritional compounds which only the specific microorganism can catabolize (O'Connell et al. 1996). The phenomenon of Agrobacterium tumefaciens mediated transfer of a region of its plasmid DNA that encodes opine biosynthesis to plant cells forms the basis of this strategy. Guyon et al. (1993) have demonstrated that opines produced by roots of transgenic plants increase the population of opine-catabolizing Agrobacterium. Similar results have also been obtained by Mansouri et al. (2002) who reported that transgenic Lotus plants producing opines specifically favor the growth of opine-degrading rhizobacteria, irrespective of soil type and plant species.

Plants may also be engineered for the production of recombinant proteins in order to overcome the difficulties involved in introducing complex antibiotic synthesis machinery in plants for inhibiting the growth of antagonists. Transfer of genes encoding inhibitory proteins and peptides to plants enables their diffusion into the rhizosphere resulting in the growth of only selected soil microorganisms. This approach is being studied for possible applications in the control of soilborne pathogens. Pathogens infect plant tissues by producing a wide array of plant cell wall degrading enzymes. To prevent this, polygalacturonase-inhibiting proteins (PGIPs) that inhibit the pectin-depolymerizing activity of polygalacturonases (PGs) secreted by microbial pathogens are made use of (Kalunke et al. 2015). Transgenic tomato plants, expressing a pear (Pyrus communis L.) PGIP (PcPGIP), capable of inhibiting the PGs secreted by Bacillus cinerea showed $15 \%$ and $25 \%$ reduction of disease lesions caused by the fungus on ripening fruit and leaves, respectively (Powell et al. 2000). In another study, Jach et al. (1995) detected high-level expression of genes transferred to tobacco for the production of chitinase, $\beta$-1,3-glucanase, and ribosome-inactivating protein, under the control of the CaMV 35S-promoter. Fungal infection assays revealed that the expression of individual genes resulted in increased protection against the soil-borne fungal pathogen Rhizoctonia solani (Jach et al. 1995). Similarly, simultaneous expression of a tobacco class I chitinase and a class I $\beta$-1,3-glucanase gene in tomato resulted in increased resistance to Fusarium oxysporum f. sp. lycopersici with $36 \%$ to $58 \%$ reduction in disease severity (Jongedijk et al. 1995). Strittmatter et al. (1995) reported the inhibition of fungal pathogens by engineering controlled cell death in plants. The expression of bacterial ribonuclease barnase, driven simultaneously by a chimeric pathogen-inducible promoter (prp1-1) from potato and the CaMV 35S promoter, in order to avoid detrimental effects of the RNAse, was studied and the induction of barnase activity at the infection site was found to lead to a significant reduction of Phytophthora infestans sporulation on leaves (Strittmatter et al. 1995).

\section{Engineering microbial signaling molecules in plants to bias the rhizosphere}

Plants recognize and actively respond to different rhizosphere microorganisms by producing signals that modulate microbial colonization (Haichar et al. 2014). Hence, plant rhizosphere may be modified by engineering plants to release microbial signal molecules like isoflavonoids or lipooligosaccharides which induce microbial gene expression in the rhizosphere. This method can be effectively utilized in ensuring nodule occupancy by the appropriate rhizobial species in leguminous crop plants by utilizing nodule-specific compounds as growth enhancers (Savka et al. 2002). The regulatory mechanism of quorum sensing, which involves the synthesis and accumulation of low-molecular weight signal molecules as a function of the population density of microbes producing these molecules in a given environment, finds applications in this area (Savka et al. 2002). Several microbial functions like biofilm formation, pathogenicity, and iron uptake are regulated via quorum sensing (Abisado et al. 2018; Rutherford and Bassler 2012). The ability to generate bacterial quorum-sensing signaling molecules in the plant opens new avenues for manipulating the plant-microbe interactions. Some of the microbial signals like the N-acyl-L-homoserine lactones (AHLs) and volatile organic compounds, which belong to a class of bacterial quorum sensing signals from Gram-negative bacteria such as Pseudomonas, play a role in plant morphogenetic processes (Ortíz-Castro et al. 2009). Transgenic tobacco and tomato plants expressing the LasI gene from Pseudomonas aeruginosa, responsible for the synthesis of AHLs have been synthesized (Barriuso et al. 2008a). These AHLs produce get diffused across the plasma membranes into the rhizosphere, where they have the potential to affect bacterial processes regulated by such molecules (Ortíz-Castro et al. 2009). Providing transgenic plants with the ability to block or degrade AHL signals, otherwise termed as quorum quenching, may provide an alternative approach for engineering plant resistance to microbial pathogens. Transgenic tobacco and potato plants expressing the aiiA gene responsible for AHL degradation have shown resistance to Erwinia carotovora pv. 
carotovora infections even at very high bacterial inocula (Dong et al. 2000).

\section{Future prospects of plant-microbiome associations}

The rhizosphere microbiome facilitates communication between the plant and the surrounding soil environment and they together contribute to creating a productive metagenome which leads to improved crop productivity (Zorner et al. 2018). Studies connecting comparative genomics and metabolomics have shown that specific rhizosphere bacteria are naturally selected depending on the root exudates contents (Zhalnina et al. 2018). For instance, comparison of wild and domesticated common bean (Phaseolus vulgaris) grown in agricultural soil revealed that as the genotype transitioned from wild to domesticated, the relative abundance of Bacteroidetes (Chitinophagaceae and Cytophagaceae) decreased while Actinobacteria and Proteobacteria (Nocardioidaceae and Rhizobiaceae) increased (PérezJaramillo et al. 2017). The synergistic and complementary mechanisms among microorganisms and of plant-microbe interactions can be unveiled with the use of model plants grown under gnotobiotic conditions as such studies throw light into the phenomenon of microbiome-mediated host plant immunity (Sessitsch and Mitter 2015). Researchers have investigated immune responses elicited by plant microbiomes using the FlowPot system (Kremer et al. 2016). Microbe-free seeds of Arabidopsis were grown in sterile, bottom-irrigated pots alongside Arabidopsis colonized with diverse microbial communities from various soils. Transcriptome profiling revealed that colonized plants had significantly more defenseassociated transcripts involved in innate immunity, when exposed to speck disease of tomatoes, caused by Pseudomonas syringae pv tomato. The study also revealed a microbiomeinfluenced host and pathogen gene expression and suggested a "plant-pathogen-microbiome disease triangle" concept for advanced studies of microbial pathogenesis and plant disease resistance. The phenomenon of transfer of microbiome, from disease-suppressive soils to pathogen prevalent soils, for management of crop diseases has also been reported (Gopal et al. 2013; Turner et al. 2013).

Due to the direct influence of microbial interactions on plants and the ability of host plants to mediate microbiome assembly, selection on a host-microbial association is an emerging approach to enhance plant fitness and productivity (Mueller and Sachs 2015). Protocols may be designed targeting the selection of a characteristic host phenotype affected by the microbiome function which then gradually facilitates the transfer of specific trait-associated microbiomes into new plant hosts (Fig. 1). Such studies describing the ability of plant-associated microbiomes to influence different
Pooling rhizosphere samples of crop species with specific phenotype growing under different environmental and soil conditions

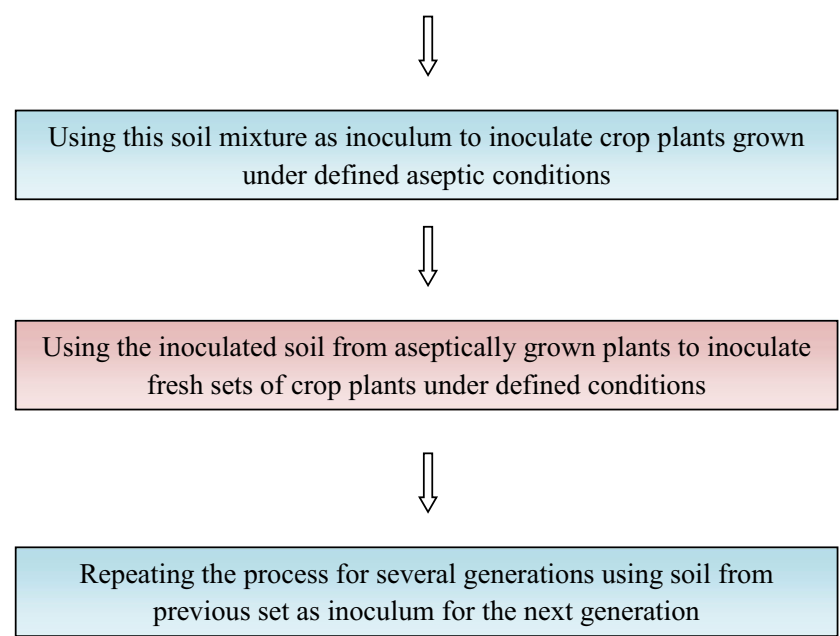

Fig. 1 Process of identification of trait-specific microbiome associated with crop plants. The synergy of plant-microbiome associations forms the basis of this selection which can be utilized to enhance plant fitness and productivity

plant traits including growth, flowering, and abiotic stress tolerance have been reported (Bainard et al. 2013; Sugiyama et al. 2013). Panke-Buisse et al. (2015) used a multigeneration experimental system using Arabidopsis thaliana Col to select for soil microbiomes inducing earlier or later flowering times of their hosts. They found that the flowering phenotype was reproducible across plant hosts which showed shifts in flowering time corresponding with the inoculation of early or late flowering microbiomes. Moreover, this resulted in a mutual selection of plant host and the surrounding microbiome (Hunter 2016). As the host plants get coevolved with their microbiome, this strategy of microbiome selection could be adopted in future crop breeding strategies for low-input sustainable agriculture. Also, the hologenome of host-microbiome association functions as an intermediate between the genotype-environment interaction in shaping the host plant phenotype (Hassani et al. 2018). Considering the functional significance of plant-microbe interactions, an indepth study into the microbiome function, particularly, the microbiome constituents that are active during the different developmental stages of plant growth and their functions is needed (Mendes et al. 2013).

Genetic improvement of plants focused on an efficient interaction with beneficial microorganisms and selection of agricultural practices with less adverse effects on microbiome therefore need to be evolved (Gopal and Gupta 2016; Sessitsch and Mitter 2015). Application of such works in the field, as opined by Hunter (2016) would permit crops to exploit the beneficial microorganisms in soil, as several commercial crop varieties have lost this capability due to injudicious use of chemical amendments. 


\section{Compliance with ethical standards}

Conflicts of interest The authors declare that they have no conflict of interest.

Ethical approval No studies with humans/animals have been performed by any of the authors for the purpose of this review article.

Informed consent Informed consent was obtained from all the authors and the authors agreed to the manuscript being submitted to the journal.

Publisher's note Springer Nature remains neutral with regard to jurisdictional claims in published maps and institutional affiliations.

\section{References}

Abisado RG, Benomar S, Klaus JR, Dandekar AA, Chandler JR (2018) Bacterial quorum sensing and microbial community interactions. mBio 9(3):e02331-e02317

Ahmad P, Hashem A, Abd-Allah EF, Alqarawi AA, John R, Egamberdieva D, Gucel S (2015) Role of Trichoderma harzianum in mitigating $\mathrm{NaCl}$ stress in Indian mustard (Brassica juncea L.) through antioxidative defense system. Front Plant Sci 6:868

Ahmed S, Rahman MS, Hasan MM, Paul N, Sajib AA (2018) Microbial degradation of lignocellulosic biomass: discovery of novel natural lignocellulolytic bacteria. BioTechnologia 99(2)C):137-146

Antoun H, Kloepper JW (2001) Plant growth promoting rhizobacteria (PGPR). In: Brenner S, Miller JH (eds) Encyclopedia of genetics. Academic Press, New York, pp 1477-1480

Atieno M, Hermann L, Okalebo R, Lesueur D (2012) Efficiency of different formulations of Bradyrhizobium japonicum and effect of coinoculation of Bacillus subtilis with two different strains of Bradyrhizobium japonicum. World J Microbiol Biotechnol 28: 2541-2550

Badri DV, Vivanco JM (2009) Regulation and function of root exudates. Plant Cell Environ 32:666-681

Bainard LD, Koch AM, Gordon AM, Klironomos JN (2013) Growth response of crops to soil microbial communities from conventional monocropping and tree-based intercropping systems. Plant Soil 363: 345-356

Bakker M, Manter D, Sheflin A, Weir T, Vivanco J (2012) Harnessing the rhizosphere microbiome through plant breeding and agricultural management. Plant Soil 360:1-13

Barriuso J, Ramos-Solano B, Fray PG, Cámara M, Hartmann A, Gutierrez-Mañero FJ (2008a) Transgenic tomato plants alter quorum sensing in plant growth-promoting rhizobacteria. Plant Biotechnol J $6: 442-452$

Barriuso J, Ramos-Solano B, Lucas JA, Lobo AP, García-Villaraco A, Mañero FJG (2008b) Ecology, genetic diversity and screening strategies of plant growth promoting rhizobacteria (PGPR). In: Ahmad I, Pichtel J, Hayat S (eds) Plant-bacteria interactions: strategies and techniques to promote plant growth. Wiley-VCH Verlag $\mathrm{GmbH} \&$ Co. KGaA, Weinheim, pp 1-17

Bhardwaj D, Ansari MW, Sahoo RK, Tuteja N (2014) Biofertilizers function as key player in sustainable agriculture by improving soil fertility, plant tolerance and crop productivity. Microb Cell Factories 13:66

Bigirimana J, Höfte M (2002) Induction of systemic resistance to Colletotrichum lindemuthianum in bean by a benzothiadiazole derivative and rhizobacteria. Phytoparasitica 30:159

Black R, Tinker PB (1979) The development of endomycorrhizal root systems. II. Effect of agronomic factors and soil conditions on the development of vesicular-arbuscular mycorrhizal infection in barley and on the enophyte spore density. New Phytol 83:401-413

Bömke C, Tudzynski B (2009) Diversity, regulation, and evolution of the gibberellin biosynthetic pathway in fungi compared to plants and bacteria. Phytochem 70(15-16):1876-1893

Bottini R, Cassán F, Piccoli P (2004) Gibberellin production by bacteria and its involvement in plant growth promotion and yield increase. Appl Microbiol Biotechnol 65:497

Brigham LA, Woo H-H, Nicoll SM, Hawes MC (1995) Differential expression of proteins and mRNAs from border cells and root tips of pea. Plant Physiol 109(2):457-463

Brundrett MC, Ferguson BJ, Gressshoff PM, Filleur S, Mathesius U, Munns R, Rasmussen A, Ryan MH, Ryan P, Schmidt S, Watt M (2016) Nutrient uptake from soils. In: Munns R, Schmidt S, Beveridge C (eds) Plants in action edition 2, Australian Society of Plant Scientists, New Zealand Society of Plant Biologists, and New Zealand Institute of Agricultural and Horticultural Science

Brussaard L, De Ruiter PC, Brown GG (2007) Soil biodiversity for agricultural sustainability. Agric Ecosyst Environ 121:233-244

Bulgarelli D, Schlaeppi K, Spaepen S, van Themaat EVL, Schulze-Lefert P (2013) Structure and functions of the bacterial microbiota of plants. Annu Rev Plant Biol 64:807-838

Caravaca F, Maboreke H, Kurth F, Herrmann S, Tarkka MT, Ruess L (2015) Synergists and antagonists in the rhizosphere modulate microbial communities and growth of Quercus robur L. Soil Biol Biochem 82:65-73

Chen YP, Rekha PD, Arun AB, Shen FT, Lai WA, Young CC (2006) Phosphate solubilizing bacteria from subtropical soil and their tricalcium phosphate solubilizing abilities. Appl Soil Ecol 34:33-41

Chen Y, Wang J, Yang N, Wen Z, Sun X, Chai Y, Ma Z (2018) Wheat microbiome bacteria can reduce virulence of a plant pathogenic fungus by altering histone acetylation. Nat Commun volume 9 , article number:3429

Chongbiao Y (1990) Associative nitrogen-fixation of rice rhizosphere. Agricultural Publishing House, Hanoi, pp 294-297

Costacurta A, Vanderleyden J (1995) Synthesis of phytohormones by plant-associated bacteria. Crit Rev Microbiol 21(1):1-18

Costerousse B, Schönholzer-Mauclaire L, Frossard E, Thonar C (2018) Identification of heterotrophic zinc mobilization processes among bacterial strains isolated from wheat rhizosphere (Triticum aestivum L.). Appl Environ Microbiol 84(1):e01715-e01717

Cruz-Hernández A, Tomasini-Campocosio A, Pérez-Flores L, Fernández-Perrino F, Gutiérrez-Rojas M (2012) Inoculation of seed-borne fungus in the rhizosphere of Festuca arundinacea promotes hydrocarbon removal and pyrene accumulation in roots. Plant Soil 363:261-270

de Souza RSC, Okura VK, Armanhi JSL, Jorrín B, Lozano N, da Silva MJ, González-Guerrero M, de Araújo LM, Verza NC, Bagheri HC, Imperial J, Arruda P (2016) Unlocking the bacterial and fungal communities assemblages of sugarcane microbiome. Sci Rep volume 6, article number:28774

Dean R, Van Kan JA, Pretorius ZA, Hammond-Kosack KE, Di Pietro A, Spanu PD, Rudd JJ, Dickman M, Kahmann R, Ellis J, Foster GD (2012) The top 10 fungal pathogens in molecular plant pathology. Mol Plant Pathol 13(4):414-430

Doehlemann G, Ökmen B, Zhu W, Sharon A (2017) Plant pathogenic fungi. Microbiol Spectr 5(1):2 pages

Dong YH, Xu JL, Li XZ, Zhang LH (2000) AiiA, an enzyme that inactivates the acylhomoserine lactone quorum-sensing signal and attenuates the virulence of Erwinia carotovora. Proc Natl Acad Sci U S A 97(7):3526-3531

Edwards J, Johnson C, Santos-Medellín C, Lurie E, Podishetty NK, Bhatnagar S, Eisen JA, Sundaresan V (2015) Structure, variation, and assembly of the root-associated microbiomes of rice. Proc Natl Acad Sci U S A 112(8):E911-E920 
Fierer N, Jackson RB (2006) The diversity and biogeography of soil bacterial communities. Proc Natl Acad Sci U S A 103(3):626-631

Frey-Klett P, Garbaye J, Tarkka M (2007) The mycorrhiza helper bacteria revisited. New Phytol 176:22-36

Geurts R, Lillo A, Bisseling T (2012) Exploiting an ancient signalling machinery to enjoy a nitrogen fixing symbiosis. Curr Opin Plant Biol 15(4):438-443

Gévaudant F, Duby G, von Stedingk E, Zhao RM, Morsomme P, Boutry M (2007) Expression of a constitutively activated plasma membrane $\mathrm{H}^{+}$-ATPase alters plant development and increases salt tolerance. Plant Physiol 144:1763-1776

Gkarmiri K, Mahmood S, Ekblad A, Alström S, Högberg N, Finlay R (2017) Identifying the active microbiome associated with roots and rhizosphere soil of oilseed rape. Appl Environ Microbiol 83(22)pii: e01938-17

Gopal M, Gupta A (2016) Microbiome selection could spur nextgeneration plant breeding strategies. Front Microbiol 7:1971

Gopal M, Gupta A, Thomas GV (2013) Bespoke microbiome therapy to manage plant diseases. Front Microbiol 4:355

Gopalakrishnan S, Sathya A, Vijayabharathi R, Varshney RK, Gowda CL, Krishnamurthy L (2015) Plant growth promoting rhizobia: challenges and opportunities. 3Biotech 5:355-377

Guimarães AA, Jaramillo PMD, Nóbrega RSA, Florentino LA, Silva KB, de Souza Moreira FM (2012) Genetic and symbiotic diversity of nitrogen-fixing bacteria isolated from agricultural soils in the western Amazon by using cowpea as the trap plant. Appl Environ Microbiol 78(18):6726-6733

Gunawardena U, Hawes MC (2002) Tissue specific localization of root infection by fungal pathogens: role of root border cells. Mol PlantMicrobe Interact 15(11):1128-1136

Guyon P, Petit A, Tempé J, Dessaux Y (1993) Transformed plants producing opines specifically promote growth of opine-degrading agrobacteria. Mol Plant-Microbe Interact 6:92-98

Gyaneshwar P, Hirsch AM, Moulin L, Chen WM, Elliott GN, Bontemps C, Estrada-de Los Santos P, Gross E, Dos Reis FB, Sprent JI, Young JP, James EK (2011) Legume-nodulating Betaproteobacteria: diversity, host range, and future prospects. Mol Plant-Microbe Interact 24:1276-1288

Haichar F eZ, Santaella C, Heulin T, Achouak W (2014) Root exudates mediated interactions belowground. Soil Biol Biochem 77:69-80

Hartmann A, Schmid M, van Tuinen D, Berg G (2009) Plant-driven selection of microbes. Plant Soil 321:235-257

Hassani MA, Durán P, Hacquard S (2018) Microbial interactions within the plant holobiont. Microbiome 6(1):58

Hawes MC, Brigham LA, Wen F, Woo HH, Zhu Y (1998) Function of root border cells in plant health: pioneers in the rhizosphere. Annu Rev Phytopathol 36:311-327

Hawes MC, Gunawardena U, Miyasaka S, Zhao X (2000) The role of root border cells in plant defense. Trends Plant Sci 5(3):128-133

Hawes MC, Curlango-Rivera G, Xiong Z, Kessler JO (2012) Roles of root border cells in plant defense and regulation of rhizosphere microbial populations by extracellular DNA 'trapping'. Plant Soil 355: $1-16$

Hawes MC, McLain J, Ramirez-Andreotta M, Curlango-Rivera G, Flores-Lara Y, Brigham LA (2016) Extracellular trapping of soil contaminants by root border cells: new insights into plant defense. Agronomy 6(1):5

Hawkes CV, DeAngelis KM, Firestone MK (2007) Root interactions with soil microbial communities and processes. In: Cardon Z, Whitbeck J (eds) The rhizosphere. Elsevier, New York, pp 1-3

Hegde DM, Dwivedi BS (1994) PDCSR Annual Report. PDCSR, Modipuram, Meerut

Heil M, Bostock RM (2002) Induced systemic resistance (ISR) against pathogens in the context of induced plant defences. Ann Bot 89(5): 503-512
Höfte M, Bakker PAHM (2007) Competition for iron and induced systemic resistance by siderophores of plant growth promoting rhizobacteria. In: Varma A, Chincholkar SB (eds) Soil biology, volume 12: microbial siderophores. Springer-Verlag, Heidelberg

Huang B, Zhu L, Liu XY, Zhang Y, Zhao N (2009) Individual and joint effects of lead and mercury on the viability of root border cells in mung bean (Vigna radiata). In: Proceedings of the international symposium on environmental science and technology. Shanghai, China, pp 254-258

Hui Z, Shang SH, Liu J, He W, Liu XD, Xie XZ (2007) Screening of abscisic acid producing fungi and studies of its fermentation conditions. J Shenyang Institute Chem Technol 21(3):170-173

Hunter P (2016) Plant microbiomes and sustainable agriculture. EMBO Rep 17(12):1696-1699

Igiehon NO, Babalola OO (2018) Rhizosphere microbiome modulators: contributions of nitrogen fixing bacteria towards sustainable agriculture. Int J Environ Res Public Health 15(4)pii: E574

Jach G, Görnhardt B, Mundí J, Logemann J, Pinsdorf E, Leah R, Schell J, Maas C (1995) Enhanced quantitative resistance against fungal disease by combinatorial expression of different barley antifungal proteins in transgenic tobacco. Plant J 8:97-109

Jha B, Gontia I, Hartmann A (2012) The roots of the halophyte Salicornia brachiata are a source of new halotolerant diazotrophic bacteria with plant growth-promoting potential. Plant Soil 356:265-277

Jian-Wei P, Mu-Yuan Z, Hua-Zheng P, Li-Lin W (2002) Developmental regulation and biological functions of root border cells in higher plants. Acta Bot Sin 44(1):1-8

Jones D, Nguyen C, Finlay DR (2009) Carbon flow in the rhizosphere: carbon trading at the soil-root interface. Plant Soil 321:5-33

Jongedijk E, Tigelaar H, van Roekel JSC, Bres-Vloemans SA, Dekker I, van den Elzen PJM, Cornelissen BJC, Melchers LS (1995) Synergistic activity of chitinases and $\beta-1,3$-glucanases enhances fungal resistance in transgenic tomato plants. Euphytica 85(1): $173-180$

Kalunke RM, Tundo S, Benedetti M, Cervone F, De Lorenzo G, D'Ovidio $\mathrm{R}$ (2015) An update on polygalacturonase-inhibiting protein (PGIP), a leucine-rich repeat protein that protects crop plants against pathogens. Front Plant Sci 6:146

Kautz T (2015) Research on subsoil biopores and their functions in organically managed soils: a review. Renew Agr Food Syst 30(4): 318-327

Kawasaki A, Watson ER, Kertesz MA (2012) Indirect effects of polycyclic aromatic hydrocarbon contamination on microbial communities in legume and grass rhizospheres. Plant Soil 358:169-182

Knox OGG, Gupta VVSR, Nehl DB, Stiller WN (2007) Constitutive expression of cry proteins in roots and border cells of transgenic cotton. Euphytica 154:83-90

Kopittke PM, Menzies NW, de Jonge MD, McKenna BD, McKenna BA, Donner E, Webb RI, Paterson DJ, Howard DL, Ryan CG, Glover CJ, Scheckel KG, Lombi E (2011) In situ distribution and speciation of toxic $\mathrm{Cu}, \mathrm{Ni}$ and $\mathrm{Zn}$ in hydrated roots of cowpea. Plant Physiol 156:663-673

Koyama H, Takita E, Kawamura A, Hara T, Shibata D (1999) Over expression of mitochondrial citrate synthase gene improves the growth of carrot cells in Al-phosphate medium. Plant Cell Physiol 40:482-488

Kramer S, Dibbern D, Moll J, Huenninghaus M, Koller R, Krueger D, Marhan S, Urich T, Wubet T, Bonkowski M, Buscot F, Lueders T, Kandeler E (2016) Resource partitioning between bacteria, fungi, and protists in the detritusphere of an agricultural soil. Front Microbiol 7:1524

Kremer J, Paasch B, He Tiedje J, Kvitko B, Jerome J (2016) A plantpathogen-microbiome disease triangle concept. Poster session presented at: IS-MPMI (International Society for Molecular PlantMicrobe Interactions XVII conference; July 17-21; Portland 
Kurosawa E (2003) Experimental studies on the nature of the substance secreted by the "bakanae" fungus. Lancet Infect Dis 3(3):125-126

Kuzyakov Y (2009) Hotspots in the rhizosphere. Geophysical Research Abstracts 11. EGU2009-7184-2001

Kuzyakov Y, Blagodatskaya E (2015) Microbial hotspots and hot moments in soil: concept \& review. Soil Biol Biochem 83:184-199

Lareen A, Burton F, Schäfer P (2016) Plant root-microbe communication in shaping root microbiomes. Plant Mol Biol 90:575-587

Lay CY, Bell TH, Hamel C, Harker KN, Mohr R, Greer CW, Yergeau É, St-Arnaud M (2018) Canola root-associated microbiomes in the Canadian prairies. Front Microbiol 9:1188

Lilley CJ, Wang D, Atkinson HJ, Urwin PE (2011) Effective delivery of a nematode-repellent peptide using a root-cap-specific promoter. Plant Biotechnol J 9(2):151-161

López-Bucio J, de la Vega OM, Guevara-Garcia A, Herrera-Estrella L (2000) Enhanced phosphorus uptake in transgenic tobacco plants that overproduce citrate. Nature Biotechnol 18:450-453

Malusà E, Pinzari F, Canfora L (2016) Efficacy of biofertilizers: challenges to improve crop production. In: Singh DP, Singh HB, Prabha $\mathrm{R}$ (eds) Microbial inoculants in sustainable agricultural productivity. Springer, Mumbai, pp 17-40

Mansfield J, Genin S, Magori S, Citovsky V, Sriariyanum M, Ronald P, Dow M, Verdier V, Beer SV, Machado MA, Toth I, Salmond G, Foster GD (2012) Top 10 plant pathogenic bacteria in molecular plant pathology. Mol Plant Pathol 13:614-629

Mansouri H, Petit A, Oger P, Dessaux Y (2002) Engineered rhizosphere: the trophic bias generated by opine-producing plants is independent of the opine type, the soil origin, and the plant species. Appl Environ Microbiol 68(5):2562-2566

Marasco R, Rolli E, Ettoumi B, Vigani G, Mapelli F, Borin S, AbouHadid AF, El-Behairy UA, Sorlini C, Cherif A, Zocchi G, Daffonchio D (2012) A drought resistance-promoting microbiome is selected by root system under desert farming. PLoS One 7:e48479

Marschner P, Crowely D, Rengel Z (2010) Interaction between rhizosphere microorganisms and plants governing iron and phosphorous availability. $19^{\text {th }}$ world congress of soil science, Brisbane, Australia, $52-55$

McGonigle TP (1988) A numerical analysis of published field trials with vesicular-arbuscular mycorrhizal fungi. Funct Ecol 2:473-478

Meena VS, Maurya BR, Verma JP (2014) Does a rhizospheric microorganism enhance $\mathrm{K}^{+}$availability in agricultural soils? Microbiol Res 169(5-6):337-347

Meena KK, Sorty AM, Bitla UM, Choudhary K, Gupta P, Pareek A, Singh DP, Prabha R, Sahu PK, Gupta VK, Singh HB, Krishanani KK, Minhas PS (2017) Abiotic stress responses and microbemediated mitigation in plants: the omics strategies. Front Plant Sci $8: 172$

Meleigy SA, Khalaf MA (2009) Biosynthesis of gibberellic acid from milk permeate in repeated batch operation by a mutant Fusarium moniliforme, cells immobilized on loofa sponge. Bioresour Technol 100(1):374-379

Mendes R, Kruijt M, de Bruijn I, Dekkers E, van der Voort M, Schneider JH, Piceno YM, DeSantis TZ, Andersen GL, Bakker PA, Raaijmakers JM (2011) Deciphering the rhizosphere microbiome for disease-suppressive bacteria. Science 332:1097-1100

Mendes R, Garbeva P, Raaijmakers JM (2013) The rhizosphere microbiome: significance of plant beneficial, plant pathogenic, and human pathogenic microorganisms. FEMS Microbiol Rev 37(5): 634-663

Meyer SLF, Everts KL, McSpadden Gardener B, Masler EP, Abdelnabby HME, Skantar AM (2016) Assessment of DAPG-producing Pseudomonas fluorescens for management of Meloidogyne incognita and Fusarium oxysporum on watermelon. J Nematol 48(1):43-53

Mikhailouskaya N, Bogdevitch I (2009) Effect of biofertilizers on yield and quality of long-fibred flax and cereal grains. Agron Res 7:412-418
Mueller UG, Sachs JL (2015) Engineering microbiomes to improve plant and animal health. Trends Microbiol 23(10):606-617

Naveed M, Hussain MB, Zahir ZA, Mitter B, Sessitsch A (2014) Drought stress amelioration in wheat through inoculation with Burkholderia phytofirmans strain PsJN. Plant Growth Regul 73:121-131

Nobbe F, Hiltner L (1896) Inoculation of the soil for cultivating leguminous plants. U.S. patent 570813

O'Callaghan M, Gerard EM, Johnson VW (2001) Effect of soil moisture and temperature on survival of microbial control agents. NZ Plant Protect 54:128-135

O'Connell KP, Goodman RM, Handelsman J (1996) Engineering the rhizosphere: expressing a bias. Trends Biotechnol 14:83-88

Ortíz-Castro R, Contreras-Cornejo HA, Macías-Rodríguez L, LópezBucio J (2009) The role of microbial signals in plant growth and development. Plant Signal Behav 4(8):701-712

Owusu-Bennoah E, Mosse B (1979) Plant growth responses to vesiculararbuscular mycorrhiza. XI. Field inoculation responses in barley, lucerne and onion. New Phytol 83:671-679

Panke-Buisse K, Poole AC, Goodrich JK, Ley RE, Kao-Kniffin J (2015) Selection on soil microbiomes reveals reproducible impacts on plant function. ISME J 9(4):980-989

Pérez-Jaramillo JE, Carrión VJ, Bosse M, Ferrão LFV, de Hollander M, Garcia AAF, Ramírez CA, Mendes R, Raaijmakers JM (2017) Linking rhizosphere microbiome composition of wild and domesticated Phaseolus vulgaris to genotypic and root phenotypic traits. ISME J 11(10):2244-2257

Philippot L, Raaijmakers JM, Lemanceau P, van der Putten WH (2013) Going back to the roots: the microbial ecology of the rhizosphere. Nat Rev Microbiol 11:789-799

Powell ALT, van Kan J, ten Have A, Visser J, Greve LC, Bennett AB, Labavitch JM (2000) Transgenic expression of pear PGIP in tomato limits fungal colonization. Mol Plant-Microbe Interact 13:942-950

Press CM, Loper JE, Kloepper JW (2001) Role of iron in rhizobacteriamediated induced systemic resistance of cucumber. Phytopathology 91:593-598

Quiza L, St-Arnaud M, Yergeau E (2015) Harnessing phytomicrobiome signaling for rhizosphere microbiome engineering. Front plant Sci, volume 6 , Article 507, 11 pages

Raaijmakers J, Mazzola M (2012) Diversity and natural functions of antibiotics produced by beneficial and pathogenic soil bacteria. Annu Rev Phytopathol 50:403-424

Raaijmakers JM, de Bruijn I, Nybroe O, Ongena M (2010) Natural functions of lipopeptides from Bacillus and Pseudomonas: more than surfactants and antibiotics. FEMS Microbiol Rev 34:1037-1062

Ramos B, Garcia JKL, Probanza A, Barrientos ML, Mañero FJG (2003) Alterations in the rhizobacterial community associated with European alder growth when inoculated with PGPR strain Bacillus licheniformis. Environ Exp Bot 49:61-68

Rana A, Saharan B, Joshi M, Prasanna R, Kumar K, Nain L (2011) Identification of multi-trait PGPR isolates and evaluating their potential as inoculants for wheat. Ann Microbiol 61:893-900

Reddy PM, James EK, Ladha JK (2002) Nitrogen fixation in rice. In: Leigh GJ (ed) Nitrogen fixation at the Millenium Elsevier, Amsterdam pp 421-445

Richter D, deB ON-H, Fimmen R, Jackson J (2011) The rhizosphere and soil formation. In: Cardon ZG, Whitbeck JL (eds) The rhizosphere: an ecological perspective. Elsevier Academic Press, Cambridge, pp $179-198$

Rillig MC (2004) Arbuscular mycorrhizae, glomalin, and soil aggregation. Can J Soil Sci 84(4):355-363

Rogers C, Oldroyd GED (2014) Synthetic biology approaches to engineering the nitrogen symbiosis in cereals. J Exp Bot 65(8):19391946

Rubin RL, van Groenigen KJ, Hungate BA (2017) Plant growth promoting rhizobacteria are more effective under drought: a meta-analysis. Plant Soil 416(1-2):309-323 
Rudrappa T, Czymmek KJ, Paré PW, Bais HP (2008) Root-secreted malic acid recruits beneficial soil bacteria. Plant Physiol 148(3):15471556

Rutherford ST, Bassler BL (2012) Bacterial quorum sensing: its role in virulence and possibilities for its control. Cold Spring Harb Perspect Med 2(11)pii: a012427

Ryan PR, Dessaux Y, Thomashow LS, Weller DM (2009) Rhizosphere engineering and management for sustainable agriculture. Plant Soil 321:363-383

Savka MA, Dessaux Y, Oger P, Rossbach S (2002) Engineering bacterial competitiveness and persistence in the phytosphere. Mol PlantMicrobe Interact 15(9):866-874

Savka MA, Dessaux Y, McSpadden Gardener BB, Mondy S, Kohler PRA, de Bruijn FJ, Rossbach S (2013) The "biased rhizosphere" concept and advances in the omics era to study bacterial competitiveness and persistence in the phytosphere. In: de Bruijn FJ (ed) Molecular microbial ecology of the rhizosphere volume $1 \& 2$. John Wiley \& Sons, Inc., Hoboken, pp 1145-1161

Sen S, Chandrasekhar CN (2014) Effect of PGPR on growth promotion of rice (Oryza sativa L.) under salt stress. Asian J Plant Sci Res 4: $62-67$

Sessitsch A, Mitter B (2015) $21^{\text {st }}$ century agriculture: integration of plant microbiomes for improved crop production and food security. Microb Biotechnol 8(1):32-33

Sharma SB, Sayyed RZ, Trivedi MH, Gobi TA (2013) Phosphate solubilizing microbes: sustainable approach for managing phosphorus deficiency in agricultural soils. Springerplus 2:587

Shi T-Q, Peng H, Zeng S-Y, Ji R-Y, Shi K, Huang H, Ji X-J (2017) Microbial production of plant hormones: opportunities and challenges. Bioengineered 8(2):124-128

Shirley M, Avoscan L, Bernaud E, Vansuyt G, Lemanceau P (2011) Comparison of iron acquisition from $\mathrm{Fe}-$ pyoverdine by strategy I and strategy II plants. Botany 89(10):731-735

Singh S, Nain L (2014) Microorganisms in the conversion of agricultural wastes to compost. Proc Indian Natn Sci Acad 80(2):473-481

Smith JH, Allison FE, Soulides DA (1961) Evaluation of phosphobacterin as soil inoculants. Soil Sci Soc Am J 25(2):109 111

Somasundaram S, Fukuzono S, Iijima M (2008) Dynamics of root border cells in rhizosphere soil of Zea mays L.: crushed cells during root penetration, survival in soil, and long term soil compaction effect. Plant Prod Sci 11(4):440-446

Sorty AM, Meena KK, Choudhary K, Bitla UM, Minhas PS, Krishnani KK (2016) Effect of plant growth promoting bacteria associated with halophytic weed (Psoralea corylifolia L.) on germination and seedling growth of wheat under saline conditions. Appl Biochem Biotechnol 180:872-882

Spaepen S (2014) Plant hormones produced by microbes. In: Lugtenberg B (ed) Principles of plant-microbe interactions: microbes for sustainable agriculture. Springer International Publishing, Cham

Srivastava S, Yadav A, Seem K, Mishra S, Chaudhary V, Nautiyal CS (2008) Effect of high temperature on Pseudomonas putida NBRI0987 biofilm formation and expression of stress sigma factor RpoS. Curr Microbiol 56(5):453-457

Streng A, op den Camp R, Bisseling T, Geurts R (2011) Evolutionary origin of Rhizobium nod factor signaling. Plant Signal Behav 6(10): $1510-1514$

Strittmatter G, Janssens J, Opsomer C, Botterman J (1995) Inhibition of fungal disease development in plants by engineering controlled cell death. Nat Biotechnol 13:1085-1089

Stubbs VEC, Standing D, Knox OGG, Killham K, Bengough AG, Griffiths B (2004) Root border cells take up and release glucoseC. Ann Bot 93(2):221-224

Subba Rao NS (1976) Field response of legumes in India to inoculations and fertilizer applications. In: Nutman PS (ed) Symbiotic nitrogen fixation in plants. Cambridge University Press, London, pp 265-288
Sugiyama A, Bakker MG, Badri DV, Manter DK, Vivanco JM (2013) Relationships between Arabidopsis genotype-specific biomass accumulation and associated soil microbial communities. Botany-Botanique 91:123-126

Sundara Rao WVB (1974) Response of legumes to Rhizobium inoculation. Proc Indian Nat Sci Acad 40B(6):604-607

Tesfaye M, Dufault NS, Dornbusch M, Allan D, Vance CP, Samac DA (2003) Influence of enhanced malate dehydrogenase expression by alfalfa on diversity of rhizobacteria and soil nutrient availability. Soil Biol Biochem 35(8):1103-1113

Thapa S, Prasanna R (2018) Prospecting the characteristics and significance of the phyllosphere microbiome. Ann Microbiol 68:229-245

Theocharis A, Bordiec S, Fernandez O, Paquis S, Dhondt-Cordelier S, Baillieul F, Clément C, Barka EA (2012) Burkholderia phytofirmans PsJN primes Vitis vinifera L. and confers a better tolerance to low nonfreezing temperatures. Mol Plant-Microbe Interact 25(2):241249

Ton J, Van Pelt JA, Van Loon LC, Pieterse CMJ (2002) Differential effectiveness of salicylate dependent and jasmonate/ethylenedependent induced resistance in Arabidopsis. Mol Plant-Microbe Interact 15:27-34

Turner TR, James EK, Poole PS (2013) The plant microbiome. Genome Biol 14(6):209

Urbina H, Breed MF, Zhao W, Lakshmi Gurrala K, Andersson SGE, Ågren J, Baldauf S, Rosling A (2018) Specificity in Arabidopsis thaliana recruitment of root fungal communities from soil and rhizosphere. Fungal Biol 122(4):231-240

Uribe D, Sánchez-Nieves J, Vanegas J (2010) Role of microbial biofertilizers in the development of a sustainable agriculture in the tropics. In: Dion P (ed) Soil biology and agriculture in the tropics. Soil Biology, vol 21. Springer, Berlin

Uroz S, Buee M, Murat C, Frey-Klett P, Martin F (2010) Pyrosequencing reveals a contrasted bacterial diversity between oak rhizosphere and surrounding soil. Environ Microbiol Rep 2:281-288

Veresoglou SD, Menexes G (2010) Impact of inoculation with Azospirillum spp. on growth properties and seed yield of wheat: a meta-analysis of studies in the ISI Web of Science from 1981 to 2008. Plant Soil 337(1-2):469-480

Wackett LP (2013) Microbes and antibiotics. Microb Biotechnol 6(6): 740-741

Wen F, Zhu Y, Hawes MC (1999) Effect of pectin methylesterase gene expression on pea root development. Plant Cell 11(6):1129-1140

Whipps JM (2001) Ecological and biotechnological considerations in enhancing disease biocontrol. In: Vurro M, Gressel J, Butt T, Harman GE, Pilgeram A, Leger RJS, Nuss DL (eds) Enhancing biocontrol agents and handling risks, vol 339. IOP Press, Amsterdam, pp 43-51

Whiting SN, de Souza MP, Terry N (2001) Rhizosphere bacteria mobilize $\mathrm{Zn}$ for hyperaccumulation by Thlaspi caerulescens. Environ Sci Technol 35(15):3144-3150

Woo HL, Hazen TC, Simmons BA, DeAngelis KM (2014) Enzyme activities of aerobic lignocellulolytic bacteria isolated from wet tropical forest soils. Syst Appl Microbiol 37(1):60-67

Wu L, Kobayashi Y, Wasaki J, Koyama H (2018) Organic acid excretion from roots: a plant mechanism for enhancing phosphorus acquisition, enhancing aluminum tolerance, and recruiting beneficial rhizobacteria. Soil Sci Plant Nutr 64(6):697-704

Yadav J, Verma JP, Tiwari KN (2011) Plant growth promoting activities of fungi and their effect on chickpea plant growth. Asian J Biol Sci 4(3):291-299

Yang C-H, Crowley DE (2000) Rhizosphere microbial community structure in relation to root location and plant iron nutritional status. Appl Environ Microbiol 66(1):345-351

Yang Y, Liang Y, Han X, Chiu T-Y, Ghosh A, Chen H, Tang M (2016) The roles of arbuscular mycorrhizal fungi (AMF) in 
phytoremediation and tree-herb interactions in $\mathrm{Pb}$ contaminated soil. Sci rep volume 6, article number: 20469

Yeoh YK, Paungfoo-Lonhienne C, Dennis PG, Robinson N, Ragan MA, Schmidt S, Hugenholtz P (2016) The core root microbiome of sugarcanes cultivated under varying nitrogen fertilizer application. Environ Microbiol 18(5):1338-1351

Yi H-S, Yang JW, Ryu CM (2013) ISR meets SAR outside: additive action of the endophyte Bacillus pumilus INR7 and the chemical inducer, benzothiadiazole, on induced resistance against bacterial spot in field-grown pepper. Front Plant Sci 4:122

Young IM, Crawford JW, Nunan N, Otten W, Spiers A (2008) Microbial distribution in soils: physics and scaling. In: Sparks DL (ed) Advances in agronomy, vol. 100 Elsevier academic Press Inc, San Diego, pp 81-121

Yu M, Shen R, Liu J, Chen R, Xu M, Yang Y, Xiao H, Wang H, Wang H, Wang C (2009) The role of root border cells in aluminum resistance of pea (Pisum sativum) grown in mist culture. J Plant Nutr Soil Sci 172(4):528-534

Yu X, Ai C, Xin L, Zhou G (2011) The siderophore-producing bacterium, Bacillus subtilis CAS15, has a biocontrol effect on Fusarium wilt and promotes the growth of pepper. Eur J Soil Biol 47:138-145

Yuan ZC, Liu P, Saenkham P, Kerr K, Nester EW (2008) Transcriptome profiling and functional analysis of Agrobacterium tumefaciens reveals a general conserved response to acidic conditions ( $\mathrm{pH}$ 5.5) and a complex acid-mediated signaling involved in Agrobacterium-plant interactions. J Bacteriol 190(2):494-507

Yurgel SN, Douglas GM, Dusault A, Percival D, Langille MGI (2018) Dissecting community structure in wild blueberry root and soil microbiome. Front Microbiol 9:1187

Zamioudis C, Pieterse CMJ (2012) Modulation of host immunity by beneficial microbes. Mol Plant-Microbe Interact 25:139-150

Zelko I, Lux A (2003) Effect of cadmium on Karwinskia humboldtiana roots. Biologia 59:205-209

Zhalnina K, Louie KB, Hao Z, Mansoori N, da Rocha UN, Shi S, Cho H, Karaoz U, Loqué D, Bowen BP, Firestone MK, Northen TR, Brodie EL (2018) Dynamic root exudate chemistry and microbial substrate preferences drive patterns in rhizosphere microbial community assembly. Nat Microbiol 3(4):470-480

Zhang H, Kim MS, Sun Y, Dowd SE, Shi H, Paré PW (2008) Soil bacteria confer plant salt tolerance by tissue-specific regulation of the sodium transporter HKT1. Mol Plant-Microbe Interact 21:737-744

Zhu Y, Wen F, Zhao X, Hawes MC (2004) Isolation of the promoter of a root cap expressed pectinmethylesterase gene from Pisum sativum L. (rcpmel) and its use in the study of gene activity. Plant Soil 265(1):47-59

Zorner P, Farmer S, Alibek K (2018) Quantifying crop rhizosphere microbiome ecology: the next frontier in enhancing the commercial utility of agricultural microbes. Ind Biotechnol (New Rochelle NY) 14(3):116-119 